\title{
Large hydropower and legitimacy: A policy regime analysis, applied to Myanmar
}

\author{
Tira Foran ${ }^{\mathrm{a}, *}$, Laur Kiik ${ }^{\mathrm{b}}$, Sullivan Hatt ${ }^{\mathrm{c}}$, David Fullbrook ${ }^{\mathrm{d}}$, Alice Dawkins ${ }^{\mathrm{e}}$, Simon Walker ${ }^{\mathrm{e}}$, \\ Yun Chen ${ }^{\mathrm{a}}$ \\ a CSIRO Land and Water, Canberra, Australia \\ b University of Oxford, UK; Tallinn University, Estonia \\ ${ }^{c}$ Mekong Program on Water, Environment and Resilience, Thailand \\ d Sunrise Energy, Singapore \\ e Australian National University, Canberra, Australia
}

A R T I C L E I N F O

\section{Keywords:}

Energy governance

Hydropower

Policy regime

Gaining public acceptance

Political ecology

Mekong

\begin{abstract}
A B S T R A C T
Hydropower development in capacity-constrained countries can unfold through unsound policy arguments, narrow institutional and implementing arrangements, and ad hoc decision making processes. To derive insights for more legitimate policy making, we provide the first holistic account of Myanmar's legitimation struggles over large hydropower, focusing on Myitsone, the country's most controversial dam, during the period 2003-2011. Our analysis takes a policy regime perspective (specifically, a "political economic regime of provisioning" framework). Among our findings: (1) frequent use of non-rationally persuasive argument among contending actors; (2) a spiral of declining policy legitimacy, which is amplified by civil society mobilization, and halted by a 2011 decision to suspend Myitsone; (3) rejection of Myitsone but conditional acceptance of large hydropower among some elements of civil society. Opportunity and capability for more technically informed, inclusive discussion exists in Myanmar, but given hydropower's complexities, urgently deserves to be augmented. Although Myitsone in Myanmar is an exceptional case, we offer three propositions to assess and improve policy legitimacy of hydropower.
\end{abstract}

\section{Introduction}

How do developing countries legitimate large-scale energy infrastructure development? We engage with the above research question and profound governance challenge by exploring struggles over the legitimacy of a gigawatt-scale hydropower project in Myanmar, a leastdeveloped country torn by decades of authoritarian rule and civil war. Since 2000, a number of generalized governance frameworks and guidelines have emerged which claim relevance to the hydropower sector. All emphasize legitimated development (e.g. Mekong River Commission et al., 2010; Natural Resources Governance Institute, 2014; World Commission on Dams, 2000). The most prominent of this normative governance literature is the WCD (2000), which considered "gaining public acceptance" as the first of its seven strategic priorities. WCD conceptualized public acceptance as an outcome of equitable decision making processes. Such processes include informed participation of involuntary risk-bearers, and agreements negotiated via accountable practices (2000: 215-220). Legitimate outcomes include fair benefit sharing, and sustained rivers and livelihoods (WCD, 2000: 234-243;
Dore and Lebel, 2010).

The legitimation of large energy projects has been difficult to achieve. The implied standards of governance demand a level of capability and responsiveness which many states do not have. Existing socio-political divisions may exacerbate unaccountable decision making. In poor developing countries the gap between governance principles and socio-political reality can be significant. The WCD (2000) and related governance literature does not adequately deal with the question we raise, namely how, in specific low-capacity developing country contexts, "public acceptance" is to be improved.

Answering the question of how developing countries legitimate large-scale energy infrastructure demands analysis of policy formation and implementation in specific settings. We focus on the case of Myitsone Dam in Myanmar's northernmost Kachin State (named after the area's predominant ethnic Kachin people) during 2003-2011. Myanmar's 2011 suspension of this contested \$US3.6 billion energy project was unprecedented (Zhu et al., 2016). Academic accounts focus on various facets relevant to legitimation, for example: activism (Simpson, 2013, 2014); Kachin and Burmese nationalist politics (Kiik,

\footnotetext{
* Correspondence to: CSIRO Land and Water, GPO Box 1700, Canberra 2601, Australia.

E-mail address: tira.foran@csiro.au (T. Foran).
} 
2016b); the role of Chinese energy developers and Sino-Myanmar relations (Lamb and Dao, 2017; Perlez, 2006; Sun, 2012; Yeophantong, 2016a, 2016b), environmental and social safeguard norms (Kirchherr et al., 2016b, 2017), perceptions of environmental risk and elite corruption (Kirchherr et al., 2016a) and the role of expert knowledge in decision making (Zhu et al., 2016). Such analyses illuminate a complex case and its context, while suggesting to us that a holistic analysis of hydropower legitimation challenges is timely.

We offer a holistic account of the energy policy legitimation challenge in Myanmar. Taking a policy regime perspective (Foran et al., 2016; May and Jochim, 2013), we assess socio-technical contexts, policy arguments, institutional arrangements, and dynamics of support and opposition over time related to Myitsone Dam.

Our account enhances the literature in several respects. First, since legitimation is historically- and culturally-structured, we argue that social historical approaches (e.g. Kiik, 2016b) provide essential insights, complementing policy approaches which focus on contemporary governance practices (including social or environmental safeguards approaches). Thus we emphasize, among other dynamics, how Kachin civil society resistance against Myitsone is shaped by prior and ongoing interactions between the military-state and the Kachin Independence Organization (KIO), the quasi-state that has governed large parts of the ethnic Kachin region since the 1960s (Section 7).

Second, a topic of vital relevance to policy legitimation - yet underexplored in the Myitsone literature - is whether a particular project is the best energy services development option in a particular context (WCD, 2000). At critical moments, legitimacy may be more influenced by elite argumentation around such questions than historical or contemporary governance practice perspectives necessarily acknowledge. Thus, we analyze how values and optimality are constructed and debated by Myitsone's proponents and opponents, focusing on rational and non-rational persuasiveness.

Third, origins and impacts of civil society mobilization around Myitsone Dam are critical to understand (Chan, 2017; Kiik, 2016b; Kirchherr et al., 2017). Kachin and Burmese nationalisms were key drivers of mobilization which contributed to Myitsone's (de)legitimation (Kiik, 2016b). Decisions not to heavily censor or detain critics facilitated anti-Myitsone opposition to emerge in lowland Myanmar in 2011 (Chan, 2017). Domestic opposition provided a bargaining position for Myanmar to revoke (not revise) an inter-state hydropower agreement (Chan, 2017); it was also a "root cause" for Chinese developers to adopt more rigorous social safeguard norms (Kirchherr et al., 2017: 535). Taking mobilization seriously, we conceptualize it as a process of interaction between challengers (e.g. anti-dam networks, armed ethnic organisations) and incumbents. Responding to perceptions of threat or opportunity, incumbents (e.g. state factions, developers, policy advisors) also engage in innovative action, changing structures of opportunity, with contingent outcomes (Chan, 2017; McAdam et al., 2001; Tilly, 1999). Such dynamics make unintended consequences inevitable.

Section 2 introduces the conceptual framework, while Section 3 summarizes methods. Section 4 introduces Myanmar's development context. Sections 5-7 unpack Myanmar's policy regime around large hydropower. Section 8 discusses insights for hydropower policy, and Section 9 concludes.

\section{Conceptualizing legitimacy}

The concept of state legitimacy essentially refers to evaluations by citizens, expressed through actions and attitudes, that the state is meeting their reasonable interests. State legitimacy encompasses three interacting dimensions (Gilley, 2009):

legality (i.e. accountability to formalized rules and procedures);

citizen consent

moral justification (i.e. the actions of authorities can be justified because they serve a shared understanding among citizens of the "common good")

Although moral justification is central, in deeply divided societies such as Myanmar a shared understanding of the common good ${ }^{1}$ may not exist, making state legitimacy impossible by definition (cf. Gilley, 2009: 4-5). For us, this means that it is crucial to understand historical processes which enable or impede such shared understanding.

Gilley's (2009) conceptualization resonates with WCD (2000) and subsequent literature on the legitimation of large dams. Dore and Lebel (2010) argue that "gaining public acceptance" is an outcome of a dozen governance processes, ${ }^{2}$ but do not analyze real-world cases of legitimation. We approach legitimation through the concept of "policy regime": the governing arrangements for addressing a policy problem or issue (May, 2015; May and Jochim, 2013). This approach draws on fundamental concepts such as actors' interests, prevalent discourses, and institutions (Foran, 2006; Hajer, 1995; John, 1998; Lichbach and Zuckerman, 1997). Both interests and discourses drive politics but in a manner shaped by institutions. Discourses (e.g., specific models of economic development) can shape individual preferences. However, such models can be attacked for failing to resonate with an audience's experience, its cultural beliefs, or empirical "facts". Institutions reproduce legitimating practices yet they can be disrupted if their rationality is challenged often enough and loudly enough by outside actors. Individuals can be threatened or persuaded to conform, but can also engage in collective action (e.g., advocacy networks) (Foran, 2006, 2015).

A "policy regime" consists of a set of core arguments which represents the issue in a particular way; institutional arrangements that channel attention and resources to more or less effectively deal with the issue as defined; and different interest groups which support or oppose the governing arrangements as they unfold over time (May and Jochim, 2013). The concept emphasizes understanding the effectiveness of policy, once formulated, in governing. A legitimate regime achieves synergies between the core policy argument, effective institutional arrangements, net political support, and broad-based empowerment over time (May and Jochim, 2013). From this perspective, policy legitimacy means acceptance by the governed of the core policy arguments and institutional arrangements for resolving problems (May, 2015).

\subsection{Political economic regime of provisioning framework}

Emphasizing the need for greater critical contextualization, subsequent contributors proposed a "political economic regime of provisioning" (PERP) framework (Foran, 2015; Foran et al., 2016). The framework comprises topics relevant to an analysis of legitimation (Table 1). For example, it emphasizes the importance of natural resource-related capital accumulation, uneven development, and dispossession as sources of grievances, and hence potential catalysts of contention (Watts, 2012; Webber, 2012; Woods, 2011).

Drawing from science and technology studies, the framework emphasizes the importance of mature technology and existing infrastructure in legitimizing particular conceptions (e.g. a centralized power generation system) of what is essential for energy provisioning (Fullbrook, 2016; Hennig, 2016; Smits, 2016).

Drawing on social movement studies, and critical realist methodology (Mayntz, 2004; Sayer, 1999), the framework treats social mobilization as a potentially robust social process - that is, a process whose internal mechanisms may be discerned across disparate social contexts, including extreme contexts such as Myanmar (McAdam et al.,

\footnotetext{
${ }^{1}$ Defined as a citizen's own fair share of the gains from social cooperation, as well as the reasonable demands of fellow citizens (Gilley, 2009).

${ }^{2}$ These processes map to dimensions of governance such as: representation, distribution of authority, institutional capacity, and downward accountability (Ratner et al., 2013).
} 
Table 1

Political economic regime of provisioning.

\begin{tabular}{|c|c|}
\hline Dimension & Selected Themes \\
\hline \multicolumn{2}{|l|}{ (1) Political economic context of (energy) development: } \\
\hline \multirow[t]{2}{*}{ 1.1 Prevailing social relations } & State building; distribution of authority \\
\hline & State-society relations (e.g. political freedoms, citizenship rights) \\
\hline \multirow[t]{3}{*}{ 1.2 Patterns and vectors of resource and energy flows } & Resource exploitation strategies \\
\hline & Distribution of profits and rents \\
\hline & Distribution of access to energy services between different groups in society \\
\hline 1.3 Material infrastructure providing such flows & Energy generation \& distribution infrastructure \\
\hline \multicolumn{2}{|l|}{ (2) A multi-layered system of mental conceptions } \\
\hline 2.1 Policy arguments & Proponents' and opponents' arguments (composed of: values, issue representations, goals, and means-goal arguments) \\
\hline \multirow[t]{4}{*}{ 2.2 Formalized rules \& customary practices } & Electricity system planning practices \\
\hline & Project approval practices \\
\hline & Processes to gain the acceptance of involuntary risk-bearers \\
\hline & Project procurement (e.g. public-private partnerships) \\
\hline \multirow[t]{3}{*}{ (3) Interaction between incumbents, and challengers } & Persuasiveness of policy argumentation \\
\hline & Receptiveness of incumbents to reformist policy arguments \\
\hline & Social mobilization to resist or support particular siting decisions or plans \\
\hline
\end{tabular}

Source: authors.

2001). By mobilization, we mean a series of relational and discursive processes whereby actors conceive a threat (or opportunity) and begin to engage in innovative collective action, adapting existing organisational identities and structures to do so (McAdam et al., 2001). The interaction between challengers and incumbents - at times direct, always argumentative - results in contingent outcomes and potentially dynamic changes to the policymaking context (e.g. Chan, 2017).

\subsection{Analysis of argumentation}

Policy arguments, rules and practices (e.g. hydropower implementation practices) all make claims for collective action. We propose that they can be analyzed as "practical arguments". A practical argument involves:

[T] he "weighing" of pros and cons ... How well the claim for action is supported will depend on how a certain person will weigh [different considerations] together and how thoroughly and imaginatively she will explore as many relevant considerations as possible, including different and possibly conflicting goals, likely consequences, moral implications, different conceptualizations of the context of action ... Fairclough and Fairclough (2012: 38) [emphasis added].

Some arguments could be rationalizations, invoked to disguise decision makers' actual motivations (Flyvbjerg, 1998). Nonetheless, since justification is integral to modern political legitimacy, tracing the structure and flow of such argument is relevant.

Practical arguments consist of four components: (1) values, which are statements about what matters (or should matter) to an actor; (2) representations of the problem or issue; (3) goals, which are descriptions of desired future states, in which values are realized; and (4) means-goal arguments, i.e. arguments about how to move the situation from the problem (as represented) to the goal, in accordance with the actor's values (Fairclough and Fairclough, 2012). Topics such as effective institutional designs and implementation arrangements (Section 6) can be analyzed as means-goal arguments. Considering the four components explicitly allows different claims for action (such as building the Myitsone Dam, vs. an alternative energy project) to be compared and assessed from a variety of considerations. One important question is whether a course of action will have consequences that undermine its goal, or other collective goals (Section 7.3).

\subsection{Research questions}

How do developing countries legitimate large-scale energy infrastructure development? Addressing this central research question from a policy regime perspective and PERP framework leads us to ask:

(a) In which development contexts is Myanmar's large hydropower regime embedded? (Section 4)

(b) What is the core policy argument in favour of large hydropower development? (Section 5)

(c) What are the core institutional arrangements, and how effective are they at channelling resources and attention at addressing the issues framed by (b)? (Section 6)

(d) Given the development context, what dynamics of support or opposition ensue from attempts to implement (b), via (c)? (Section 7)

(e) What implications follow for the development of legitimate hydropower policy regimes? (Section 8)

\section{Methods}

The analysis is a synthesis of diverse sources of evidence. Consistent with case study methodology (Yin, 2013), we used multiple sources of evidence, including data already published in other studies. In approximate declining order of importance for the analysis, the data used included: peer-reviewed publications, unpublished documents, news media reports, and interviews. We sourced literature relevant to exploring the Myitsone case from a policy regimes perspective - primarily English texts, supplemented by texts in Burmese and Chinese. ${ }^{3}$ Published literature was selected using several strategies. Using combinations of keywords "Myitsone" "legitimacy" and "hydropower" we searched Google Scholar and Web of Science for work published 1900-2017. We re-analyzed 14 interviews collected as part of two previous studies (Kiik, 2016b; Zhu et al., 2016), conducted two new key informant interviews (Appendix 1), and accessed useful unpublished material (e.g. Anonymous, 2012b; Limond and Aung, 2015). One coauthor engaged in approximately 10 months of ethnographic fieldwork in Myanmar, between 2010 and 2015. The fieldwork covered topics relevant to socio-political contexts (Section 4), and dynamics of actor support and opposition to the Myitsone project (Section 7). Following ethics conventions in research involving human subjects, identities of individuals or groups are not disclosed.

We conducted a software-assisted, manual content analysis of the data. Themes used to structure the analysis are derived from the PERP framework (Table 1, second column). With respect to arguments (Section 5), we focused on those made by proponents, challengers, and knowledge brokers involved in the Myitsone case, reconstructing them

\footnotetext{
${ }^{3}$ Three co-authors have command of Burmese and/or Chinese.
} 
based on the method of Fairclough and Fairclough (2012), based on reading of multiple texts. The 828-page compilation of media accounts and reports by Snider (2012) was one useful source of arguments in favour of large hydropower in Myanmar during the early 2000s.

Our analysis of institutional arrangements (Section 6) focused on those crucial for legitimacy in this context: processes for participation of involuntary risk-bearers, and outcomes such as benefit sharing and livelihood sustenance (Section 1). We also compared Myanmar's institutional arrangements for independent power production with those of its Mekong neighbors (Foran et al., 2010; Molle et al., 2009; Suhardiman et al., 2011).

To trace the dynamics of support and opposition to Myitsone and Myanmar's large hydropower policy regime 2003-2011 (Section 7), we reviewed event chronologies (e.g. Anonymous, 2012a; Zhu et al., 2016) and directly relevant analyses (Chan, 2017; Kirchherr et al., 2016b; Zhu et al., 2016). We traced the chronological flow of arguments among actors, and tracked mobilizations. Lacunae in the data make our account of high-level decision making during the month September 2011 tentative (Section 7.2.2). Overall, however, the data allow a striking image to emerge of Myanmar's large hydropower policy regime in the period 2003-2011, the focus of this paper.

\section{Development contexts}

Myanmar's heterogeneous context includes a number of basic and formidable challenges (Jones, 2013; Kattelus et al., 2014; Zhu et al., 2016). One challenge stems from tension between the central state's interest in fast-tracking energy and resource development projects, and its hitherto limited interest in inclusive, cross-sectoral planning. Political contention continues between central state and armed ethnic organisations in the periphery (Jones, 2014). The exploitation of natural resources in regions outside of the Burmese lowlands has long been an important source of power both for ethnic minority military-political organisations and the central military-state. The central government's reliance on resources stems from its relative ineffectiveness in raising revenue from broad-based strategies (Jones, 2013).

The rise of a new military government after 1988 led to increased projection of power into the periphery. Between 1988 and 2010, the size of the Tatmadaw (Myanmar Defence Services) approximately doubled. Armed ethnic opposition groups, losing support from resource-hungry China and Thailand were pressured into entering into ceasefire agreements, recognizing the territorial claims of the Myanmar government, in return for keeping control over certain territories, a share of development benefits, and the promise of future political dialogue (Callahan, 2007; Sadan, 2016).

A second challenge stems from Myanmar's rapid partial democratization (Zhu et al., 2016). In 2003, the military government began orchestrating a transition towards a quasi-democracy, which led to a new constitution in 2008, and elections in 2010. The elections were widely assessed as neither free nor fair, resulting in a victory for the military-backed Union Solidarity and Development Party (USDP). Although the military remained in control of the state apparatus, under President Thein Sein (a high-ranking general in the State Peace and Development Council [SPDC] regime) the government liberalized freedom of speech and association (including legal protest and demonstration); opened the economy to international firms and NGOs; and since 2012 allowed some parliamentary oversight of public projects (Maung Aung Myoe, 2013). Political liberalization in turn enabled greater civil society mobilization around protecting the Ayeyarwady [Irrawaddy] river against the Myitsone Dam without evident reprisal (Anonymous, 2012b; Simpson, 2013). In 2011, however, public university and government employees were discouraged from engaging in such mobilization (Interview Q).

Myanmar's power generation system at the end of 2008 - two years after proponents China Power Investment Corporation (CPI) signed an initial agreement to develop Myitsone - had a combined capacity of
$2256 \mathrm{MW}, 64 \%$ of which was from hydropower plant, $24 \%$ from gas turbine plant, and the remainder from thermal plant. At that time, the two largest plants in the system were Chinese-funded: 280 MW Lower Paunglaung and 600 MW Shweli-1, completed in 2005 and 2009 respectively (Anonymous, 2008). Myitsone's capacity, rated at $3600 \mathrm{MW}$ in the mid-2000s - later revised to $6000 \mathrm{MW}$ (Changjiang Survey Planning Design and Research Limited Corporation, 2010) - was sufficient to meet respectively $85 \%$ or $141 \%$ of projected domestic demand in 2020 (Emmerton et al., 2015). Myitsone, like other contemporary projects in Myanmar's North and East (Greacen and Palettu, 2007) was however designed to export the majority of its power through dedicated, to-be-built, high voltage lines. As a consequence of its focus on energy export, Myanmar has lagged notably in rural electrification compared to other developing countries (World Bank, 2011). In 2015, its $18 \%$ rural electrification rate among 18 developing Asian countries exceeded only DPR Korea (IEA, 2016). Consumers outside Naypyidaw experienced frequent load shedding during the 2000s, and complained about inequities in access to reliable electricity (Hla Hla Htay, 2007; Perlez, 2006). In response, some consumers invested in solar PV systems and some communities (with NGO support) in pico-hydropower solutions. Beginning in 2015, some consultants to the Ministry of Agriculture promoted a vision of grid-connected, distributed generation (Fullbrook, 2016), based on expectations that costs of solar, wind and battery technology will continue to fall into the 2030s (CSIRO, 2013; IRENA, 2016). Zhu et al. (2016) summarize contending visions of Myanmar's future electricity system as of the mid-2010s.

\section{Policy arguments}

At the basis of the large hydropower regime in Myanmar lies the argument that in order to achieve economic development and modernization, specifically large export earnings and improved electrification, large dams for hydroelectricity export are necessary wherever feasible. Fig. 1 summarizes this argument, which is constructed from analysis of Chinese Myitsone Dam proponents' public discourse (Kiik, 2016b), Burmese media accounts of electricity development during the 2000s (Snider, 2012), and an interview with a large hydropower developer with experience in Myanmar (Interview L).

The argument consists of a depoliticized combination of sub-arguments in which large storage-type hydropower serves as a technologically generic solution to meeting economically generic development objectives. Those objectives include export trade and improving supply to meet domestic needs. The argument is not unique to Myanmar large storage dams are promoted using similar arguments in Nepal and in the Mekong region. Such arguments draw on a narrative which dominated twentieth century water resources development discourse, in which rivers harnessed for electricity generation constitute economic progress (McCully, 1996; Molle et al., 2009; Zhu et al., 2016).

Fig. 2 shows our reconstruction of Kachin civil society opponents' arguments against Myitsone. In contrast with the proponents' argument, which focuses on national and regional benefits in a depoliticized manner, the Kachin civil society opponents' argument is explicitly politicized, with references to distributive justice (KDNG, 2007). The influence of the WCD (2000) framework can also be discerned (e.g. KDNG, 2007: 62-78). The Kachin civil society opponents' argument reveals a wider range of issues, ranging from locally-specific values (e.g. livelihood and cultural preservation) to concerns about inter-ethnic peace-building in Myanmar. Later, as the scale of contention shifts to lowland Myanmar (Section 7.2), anti-Myitsone arguments incorporate broader concerns, notably a Myanmar nationalist opposition to perceived Chinese domination of the economy. Both earlier and subsequent formulations invoke and contest the wider contexts in which Myanmar energy policy is embedded.

Arguments of Kachin activists against Myitsone Dam do not exhaust the developmental values and aspirations that can be found within Kachin society, the most pertinent of which are a strong desire for 


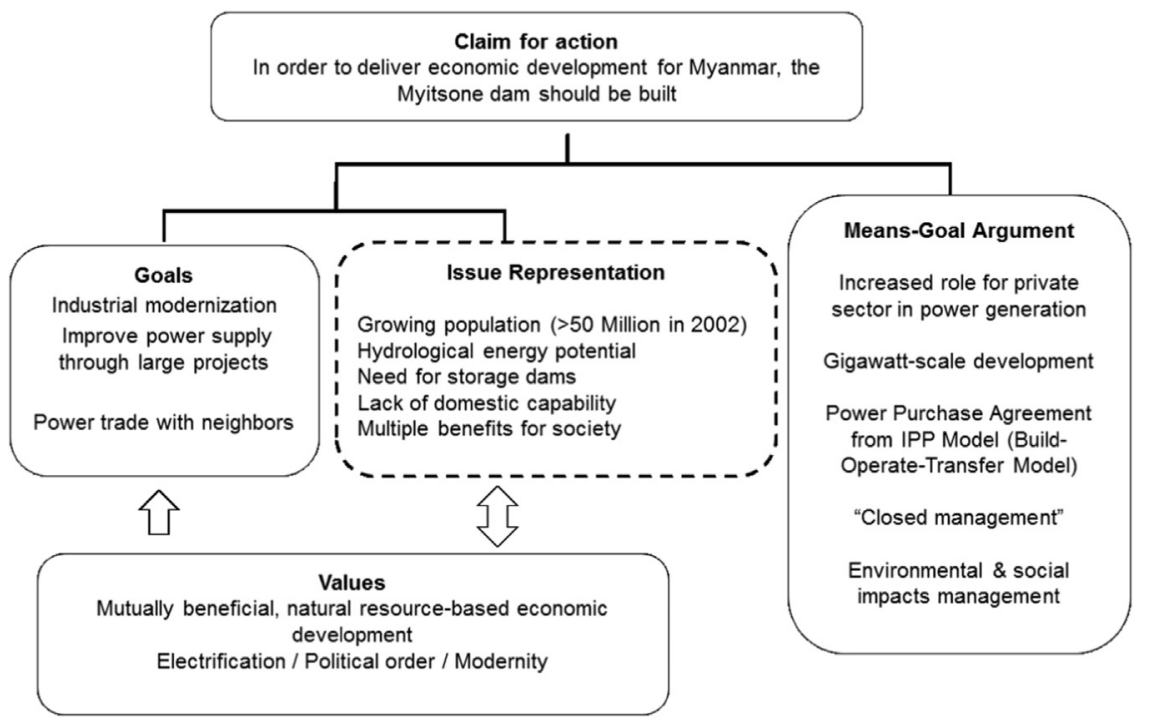

Fig. 1. Policy argument in favour of Myitsone dam and large hydropower. Source: authors.

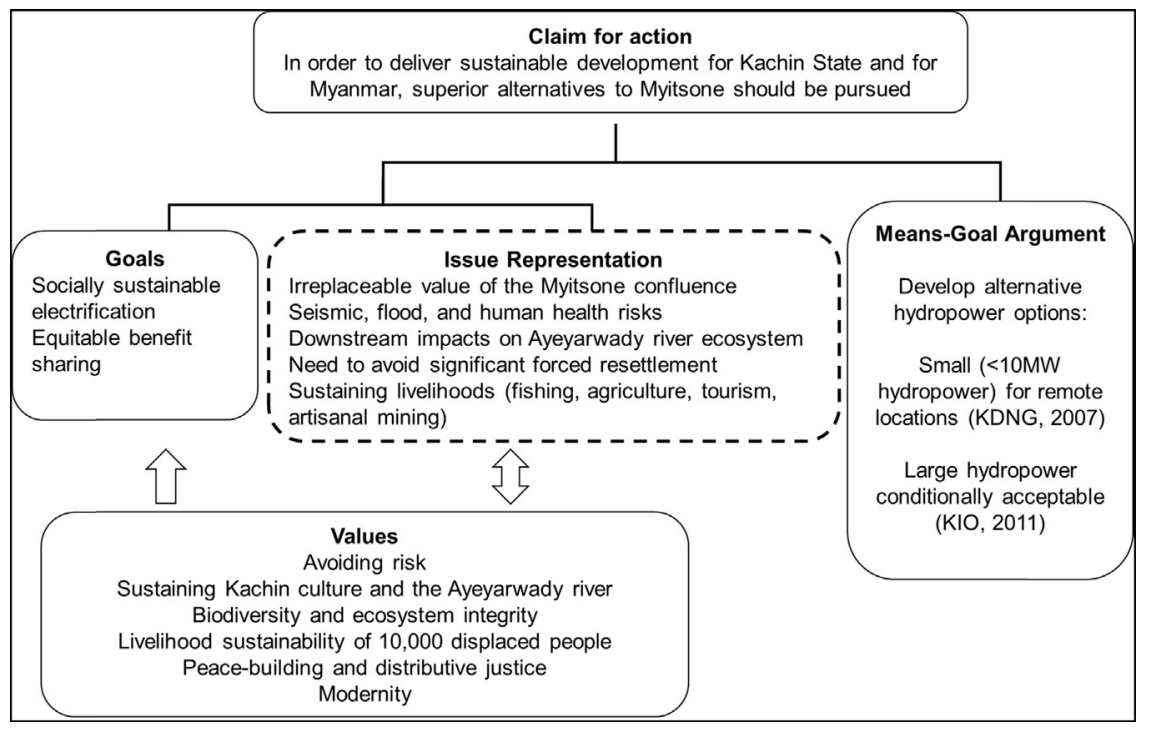

Fig. 2. Policy argument against Myitsone dam. Source: authors. ethno-national political autonomy, as well as for modernity (the latter is represented in one instance as high-rise urban development) (Kiik, 2016a). This combination of values helps explain why many Kachin actors oppose flooding the Myitsone site, framing it as an existential threat to the Kachin nation (Section 7), but do not reject all large-scale hydropower development (Fig. 2). The KIO in 2011 went so far as to argue that "we have no objection against the other six hydro plants" referring to the six other proposed dams in Fig. 1 (KIO [Kachin Independence Organization], 2011). Various Kachin activists and civilians whom a co-author interviewed from 2010 to 2015 expressed similar sentiments.

In 2011, after pro-river, anti-Myitsone mobilization emerges in urban lowland Myanmar, a debate about the pros and cons of Myitsone unfolded in different Burmese media outlets (Section 7). At this later date, proponents, notably, do not detail why Myitsone out-ranks other large-scale power generation options. Based on sources available to the authors, which do not include any feasibility studies, we cannot construct a rationally persuasive argument for why Myitsone should be chosen above other energy generation options, including the six other gigawatt-scale alternatives to be developed by CPI as the upper Ayeyarwady "cascade" (summarized in Changjiang Survey Planning Design and Research Limited Corporation (2010); Fig. 3). Proponents (e.g. Anonymous, 2011) rebutted arguments about the Myitsone site's unsuitability but failed to establish the superiority of the Myitsone site over alternatives. ${ }^{4}$

\section{Institutional arrangements}

The most striking and consequential aspect of Myitsone's institutional arrangements was the almost complete exclusion of all parties other than the project proponents and the Burmese and Chinese central governments from any significant aspect of project design and approval. Within Myanmar's central government, the Ministry of Electric Power 1 was authorized to handle the proposal. Within MOEP 1, a deputy minister unsuccessfully proposed to Minister Zaw Min that to regulate flows it would be preferable to first build a hydropower dam upstream of the Myitsone site (Su Mon Thazin Aung, 2017: 126). Otherwise, sources available to us do not include any evidence of significant intragovernmental debate, prior to proponents receiving approval in principle to proceed in 2006. Instead, allegations of corruption and opacity

\footnotetext{
${ }^{4}$ Evidence of value consists of action taken to build Myitsone first, as well as claims (which we cannot verify) that total project benefits would equal USD 54 Billion, of which the Myanmar partners would receive 60.7\% (Interview M).
} 


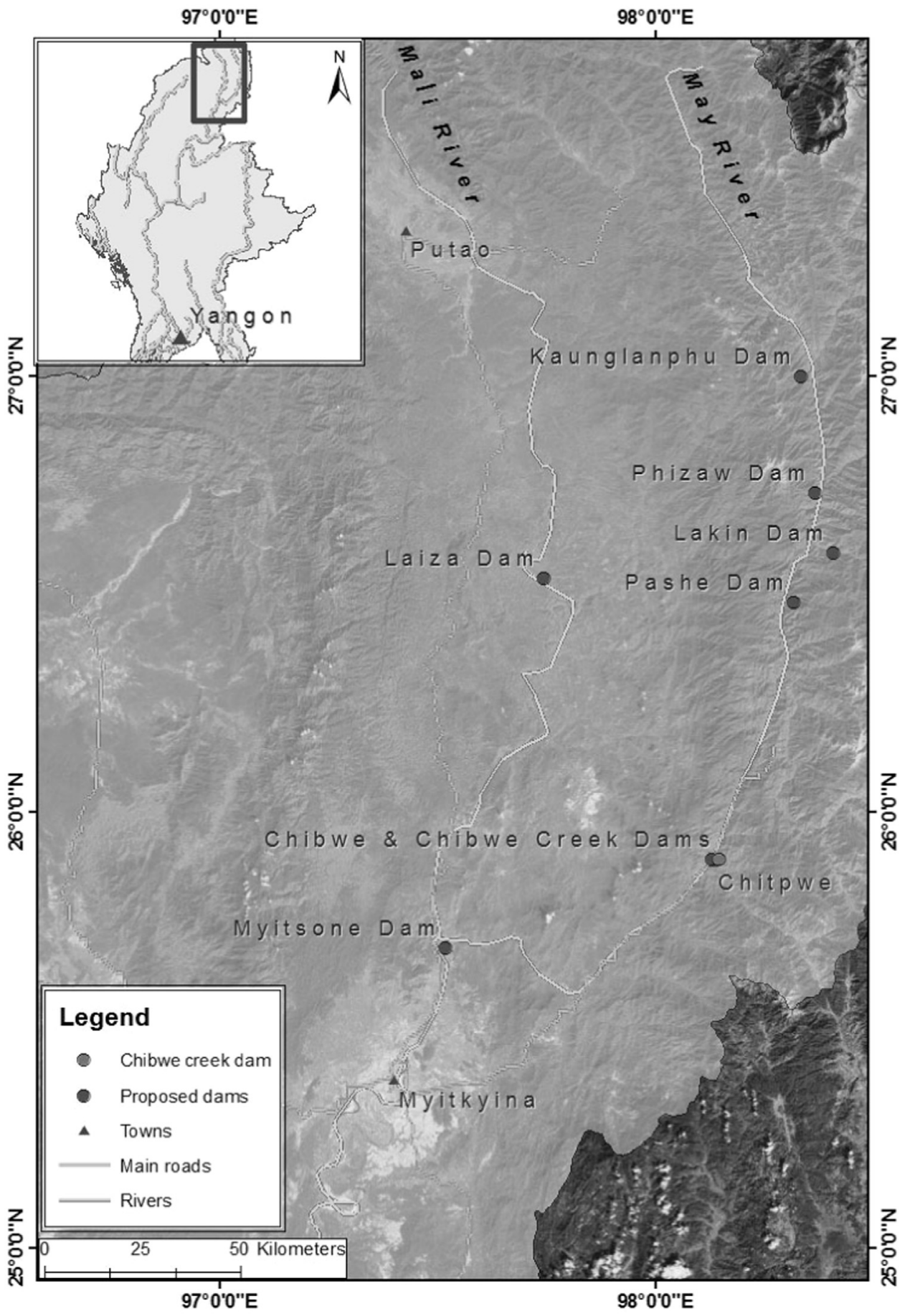

Fig. 3. Chibwe Creek dam and seven proposed upper Ayeyarwady projects. Source: based on names and locations in KDNG (2007). Notes: In Kachin, May River is N'Mai Hka and Mali River is Mali Hka.
(Kirchherr et al., 2016a, 2016b) suggest to us that rent seekers facilitated approval.

Importantly, the developers made no attempt to seek the explicit consent of project-affected people or broader public. In line with its depoliticized issue representation (Section 5), the developers adopted an explicitly "closed management" strategy. They implemented the project as if it were an "isolated island floating above the national soil of Burma," as one Chinese state agency praised (Kiik, 2016: 3-4). Such decisions assumed that Myanmar's SPDC military regime could suppress any opposition. At the time, the Myitsone confluence was controlled by the SPDC but most of the seven planned dams impinged upon the KIO territory. The relative exclusion of the KIO and the Kachin national public as beneficiaries exacerbated existing grievances (Section 7).
The formal institutional arrangements followed the general structure of a (confidential) power purchase agreement from an independent power producer. Myanmar initiated such arrangements in the 1990s. In the case of Myitsone, they also involved the Myanmar government taking an equity role in the project company (Table 2). This particular arrangement can lead to conflicted interests: on the one hand, some organ of the state is a regulator, nominally in the public interest. On the other hand, the state investor is collaborating with private sector investors in a project company designed to generate a particular stream of financial benefits. If the regulatory commitment is weak, the investors' interests may override the public interest (Foran et al., 2010). Myanmar's contemporary lack of legal requirement for EIA exacerbated the conflict of interest. However, in a decision that partially mitigated the 
Table 2

Myitsone project details. Sources: SurveyPlanningDesign and Research Limited Corporation, 2010, Interview M, Mizzima (2011)

\begin{tabular}{|c|c|c|}
\hline & \multicolumn{2}{|l|}{ Details } \\
\hline Location & \multicolumn{2}{|c|}{$\begin{array}{l}\text { Approximately } 25.71 \mathrm{~N}, 97.49 \mathrm{E} \text { (below confluence of } \\
\text { N'Mai Hka and Mali Hka rivers) }\end{array}$} \\
\hline Dam dimensions & \multicolumn{2}{|c|}{$139.5 \mathrm{~m}$ height } \\
\hline Normal water level & \multicolumn{2}{|l|}{$245 \mathrm{~m}$} \\
\hline Normal reservoir area & \multicolumn{2}{|l|}{$405 \mathrm{~km}^{2}$} \\
\hline Design head & \multicolumn{2}{|l|}{$155.3 \mathrm{~m}$} \\
\hline Installed capacity & \multicolumn{2}{|l|}{$6000 \mathrm{MW}$} \\
\hline Utilization hours & \multicolumn{2}{|l|}{5144} \\
\hline Annual energy & \multicolumn{2}{|l|}{$30,864 \mathrm{GWh}$} \\
\hline Villages submerged & \multicolumn{2}{|l|}{63} \\
\hline Affected population & \multicolumn{2}{|l|}{11,807} \\
\hline Construction period & \multicolumn{2}{|l|}{8 years } \\
\hline Total investment cost & \multicolumn{2}{|l|}{ USD 3.6 Billion } \\
\hline Sunk cost as of 2012 & \multicolumn{2}{|l|}{ USD 1.2 Billion } \\
\hline Partnership Structure & \multicolumn{2}{|l|}{ Build-Operate- } \\
\hline & Equity & Other benefits \\
\hline $\begin{array}{l}\text { China Power Investment } \\
\text { Corporation }\end{array}$ & \multicolumn{2}{|l|}{$80 \%$} \\
\hline Government of Myanmar & $15 \%$ & $\begin{array}{l}10 \% \text { of electricity } \\
\text { production free, } 8 \% \text { taxes }\end{array}$ \\
\hline Asia World Company & $5 \%$ & \\
\hline
\end{tabular}

lack of third-party appraisal, the developer commissioned an EIA, conforming to commercial lenders' expectations and also with domestic Chinese legislation.

As late as mid-2011, the USDP government appeared to believe that concern over the environmental and social impacts of Myitsone (e.g. as expressed by Kachin State MPs in March, and by Aung San Suu Kyi in July and August) could be mitigated by investing in "environmental conservation." Some of these investments were discursive (name changes to particular state organisations) (Su Mon Thazin Aung, 2017: 128, 131). Other measures publicized by MOEP in August 2011 as "environmental conservation" include commitments to resettle displaced people with no adverse effects on social affairs. The fact that resettlement had already resulted in significant adverse impacts (Section 7.2) was not acknowledged in such communication (cf. Anonymous, 2011).

\section{Dynamics of support and opposition}

Broadly speaking, the dynamics of interaction over the Myitsone project during the period 2003-2011 follow the pattern of:

Implementation (of closed management model) $\rightarrow$ (Kachin antidam) mobilization $\rightarrow$ repression $\rightarrow$ scale shift $\rightarrow$ (multi-level anti- and pro-dam) struggle $\rightarrow$ concession

Italicized terms represent robust social processes (sensu McAdam et al., 2001). A similar pattern was found to recur in struggles over the approval, construction, and operation of Thailand's most controversial dam (Foran, 2006; Missingham, 2003). Some scholars of contentious politics regard \{mobilization $\rightarrow$ struggle $\rightarrow$ concession\} dynamics as constitutive of democratization (McAdam et al., 2001).

The concession consists of President Thein Sein's 30 September 2011 decision to suspend the project during the period of his government. We defined mobilization in Section 2. By repression, we mean any deliberate action by authorities or bystanders that increases the difficulties of collective action (e.g. violence, intimidation, inaction, media attacks) (Foran, 2006).

As we describe below, beginning in 2009 the geographic and political scales of contention shift. Before 2010, anti-Myitsone contention was non-violent, taking the form of petitions, publications, and antidam graffiti, which the authorities ignore or repress through arrests of activists. After 2010, the contention intensified, involving forceful resettlement and violence at the local level, the KIO's more publicly declared opposition, followed by a resumption - for reasons beyond Myitsone - of armed conflict in June 2011 (Sadan, 2016).

\subsection{Mobilization and repression, 2003-2009}

Early attempts at anti-dam mobilization consist of several rounds of petitions, directed both at Kachin authorities and the military government. In 2003, Kachin church leaders in Tangphre village learn about dam construction plans and in early 2004 write letters of concern, without reply from Burmese authorities, nor from the KIO (Kiik, 2016b).

The position of the KIO with respect to Myitsone deserves analysis. Like other quasi-state organisations, the KIO has interests in natural resources extraction and trade (Jones, 2014), as well as in hydropower projects supplying electricity to state capital Myitkyina (population 307,000) (Transnational Institute, 2011). The KIO's relations with the Myanmar and Chinese states reflect a complex political geography (Dean, 2005). Due to political, military, and business considerations, the KIO cannot easily oppose a Chinese hydropower project in the Kachin region. ${ }^{5}$ KIO's opposition to the Myitsone Dam seems to largely stem from increasing responsiveness to Kachin social leaders and public (Interview D).

The KIO - an organization with approximately 10,000 soldiers stands to benefit economically from a peace agreement with Myanmar, which would allow it to tax and trade legitimately. In February 1994, the military government signed a ceasefire agreement which recognized KIO's claim to large territories in ethnic Kachin areas (Dean, 2005). During the 1994-2011 ceasefire period, the KIO assumes the role of a responsible, peace-making state. For example, it keeps the ceasefire despite incidents of torture and murder perpetuated against its soldiers in 2001-06 (Ba Kaung, 2011), and participates in a lengthy process to draft the 2008 Constitution. Yet, it loses much Kachin popular legitimacy because of its leaders' perceived business corruption and cooperation with the reviled Burmese junta, only regaining it during the lead-up to war in 2011 (Sadan, 2016). During this period, the KIO's position with respect to Myitsone is cooperative and restrained.

Anti-Myitsone mobilization within broader Kachin society however gradually forms in the mid-2000s, taking the form of petition campaigns and reports compiled by activists based on underground research (Kiik, 2016b, Kirchherr, 2016b). An anti-dam storyline circulates through church and activist organisations, in Kachin society and outside Myanmar. In the following years, the project is increasingly opposed as another example of large-scale resource grabbing and social injustice, creating an altogether existential threat (Kiik, 2016a). These concerns are echoed in a 2007 letter from a group of Kachin elders to General Than Shwe, head of the SPDC government:

The Irrawaddy River is the heart of Burma flowing from north to south ... rich in heritage forests and natural resources. The Irrawaddy offers survival to the Kachin people as well as to the Burmese people. The Burmese people must preserve the valuable natural resources and cultural heritage of the Irrawaddy ... for new generations. (KDNG 2007, emphasis added)

The letter argues that small-scale dams are sufficient for local development, and many different electricity generation options exist for Kachin State. Soon, the KIO also communicates that it opposes building a dam at the Myitsone confluence, while supporting hydropower development elsewhere, in letters to Yunnan authorities and to the head of the SPDC government. During 2007 and after, Kachin anti-dam activists collect signatures against the dam. In two instances, student

\footnotetext{
${ }^{5}$ As evidenced in diplomatically-worded letters objecting to Myitsone, written to Yunnan Province authorities in 2007 and to the Chinese Premier in 2011 (KIO, 2011).
} 
activists spray-paint or post strong anti-dam messages in public spaces (KDNG, 2007, 2009). However, the SPDC government meets these acts with sporadic arrests. No state authority, including the KIO, takes action to halt the project.

\subsection{Scale shift, struggle and concession, 2009-2011}

By 2009-2010, a series of developments at project-level and at regional and national levels combines to shift the geographic and political scales of the anti-Myitsone mobilization. At the project level, in 2009 the number of workers increases notably at Myitsone and related sites. Some 100 experts from several institutes hired by CPI complete field investigations for an EIA study. The Burmese partner, Biodiversity and Nature Conservation Association (BANCA), submits a report highly critical of the Myitsone project (Section 7.2.1). In 2011, this report is leaked and published online. Meanwhile in April 2010, a series of small bomb blasts occurs near the dam construction site, including Asia World offices and injuring at least one Chinese worker. ${ }^{6}$ The Burmese military responds by violence against local villagers. Soon after, developers begin to implement a program of involuntary resettlement with compensation. Four villages are relocated to the first resettlement village, followed by pressure on the area's largest village (Tanghpre) to move to a second resettlement site. Kiik (2016b: 4) describes this resettlement as "a largely violent displacement of 2000 people." Kachin villagers and organisations reported difficulty accessing suitable agricultural land, and theft of compensation money paid by CPI (Anonymous, 2012a; Kiik, 2016b; Limond and Aung, 2015).

With limited connections to Kachin campaigners, some Burmese activists in lowland Myanmar begin to oppose the Dam. The repressive context inhibits direct conversation about the Dam, so they target it indirectly by highlighting the Ayeyarwady River. They organize photography exhibitions and publish books celebrating the river and its significance for livelihoods and culture (Anonymous, 2012b; Kiik, 2016b).

The intensification of anti-dam resistance, and its diversification in the form of linkages with Burmese activism, unfolds in a context of heightened political contention in Myanmar. In April 2009 the military government demands that ethnic armed groups transform into "Border Guard Forces" under Tatmadaw control. The KIO and almost all major armed groups in eastern Myanmar resist. In 2009, the Tatmadaw attacks and overruns the Kokang, one of the smaller groups, and in 2010, annuls the non-complying organisations' ceasefire agreements, putting particular pressure on the KIO. The KIO's candidates are barred from the 2010 elections. The NLD boycotts the elections over restrictions imposed by the military on their eligibility to participate. While marred by allegations of vote rigging, the elections lead to the formation of a USDP government headed by Thein Sein.

The aftermath of these developments sees armed conflict resume in Kachin State in June 2011, rupturing the ceasefire agreement of 1994. Provocations by the Northern Command of the Tatmadaw leads to fighting in contested territory around the 240 MW Dapein- 1 hydropower dam (completed in February 2011) and the proposed Dapein-2 dam downstream. Located approximately $150 \mathrm{~km}$ south of the Myitsone site, part of Dapein-1's power is allocated to a Chinese-owned nickel mine and smelter (Burma Rivers Network, 2010). The KIO no longer allows the Myitsone project's supply trucks access to the construction site, key bridges are blown up, and construction halts. (The fighting has continued and spread, with $>100,000$ people in the Kachin region displaced into crowded camps as of 2017).

The rise of Myammar's first quasi-civilian government in decades however ushers in expanded political opportunities, particularly for urban Burmese civil society. Initially, civil society activists had low

\footnotetext{
${ }^{6}$ Some sources state that four workers were killed (Yeophantong, 2016a), however others claim no casualties.
}

confidence in the military's willingness to tolerate significant reform (Chan, 2017). However, the SPDC began to release political prisoners, including Aung San Suu Kyi, in late 2010, and as noted above, in 2011 Thein Sein's government relaxes media censorship, and liberalized freedom of association.

In this context, a "Save the Ayeyarwady" movement emerges among the Burmese activist, environmental, and cultural elite. Building on field trips to Kachin state which began around 2009 (Anonymous, 2012b; Chan, 2017), parts of ethnic Kachin and Burmese civil society actors interact informally in an explicit attempt to resist what both the Kachin and Burmese activists regard as an existential threat to their peoples, to oppose the elite and foreign beneficiaries of the project, and for some activists, to try to construct an inter-ethnic movement for peace (Kiik, 2016b:11). Crucially, the lowland Myanmar campaign is driven by a narrative of existential threat to the people of Myanmar by Chinese colonialism (Kiik, 2016b; Lamb and Dao, 2017; Min Zin, 2012).

By August 2011, a heterogeneous pro-river, anti-dam coalition emerges in Myanmar. In addition to the KIO, new actors to mobilize include incoming Kachin MPs unaligned with the KIO and a broad range of Burmese activists and intellectuals. The fear of repression leads activists to organize non-confrontational literary and artistic events, which surprisingly, attract hundreds of people, including celebraties:

[A]rt shows ... became a key vehicle for the campaign ... [they received] up to 5000 people in August and September 2011, and increasingly moved from focusing on protecting 'water sources' to 'Stop the Dam'. In a daring move, in September 2011, exhibition organisers invited the country's most famous activists, entertainers, models and music stars to the opening of an art exhibition in Yangon. About half of the invitees turned up ... [and] were requested to feature with hand written signs [such as] 'stop the dam', 'protect our river' (Anonymous, 2012b).

\subsubsection{Two smaller dams: the contribution of expert knowledge}

Scholarship on the politics of Myitsone dam has to some extent neglected the contribution of expert knowledge. As we show, the arguments of certain knowledge brokers influenced policy discourse around the project. In early 2008, CPI commissioned an Environmental Impact Assessment. It hired Changjiang Survey, Planning, Design and Research Corporation (herein, "Changjiang") to manage the EIA contract. Myanmar's Biodiversity and Nature Conservation Association (BANCA) was the senior Myanmar partner on the study. BANCA is a non-profit, non-aligned professional environmental NGO. Its report was later incorporated - in a heavily censored form - into an EIA document including contributions from Chinese institutes with hydrological or environmental remits (Changjiang Survey Planning Design and Research Limited Corporation, 2010).

The BANCA (2009) report consists of a three-part environmental baseline study and biological impact assessment. While disclaiming that it is not a comprehensive impact assessment, the text is remarkable for arguing against hydropower development in the upper Ayeyarwady basin (Zhu et al., 2016). BANCA (2009) warns against the "unplanned and environmentally naive" pace of development in Myanmar (p. xxiii), and notes that the seven upper Ayeyarwady projects impact on a globally significant biodiversity hotspot, with impacts extending downstream to the delta (p. 2, 21, 36). Drawing explicitly from WCD publications, BANCA recommends inter alia, that decision makers distinguish environmentally friendly vs. threatening dams; assist affected people for up to ten years, and direct $1 \%$ of hydropower revenues to watershed protection and two new national parks $\left(10,894 \mathrm{~km}^{2}\right)$ (2009: $22,60-3,78)$.

Most notably, BANCA (2009) recommends avoiding a dam at the Myitsone site because of its irreplaceable cultural significance to the Kachin, and recommends instead construction of two upstream dams:

The best option would be ... to develop two smaller hydropower 
dams ... at appropriate two locations above the [Myitsone] confluence rivers ... If Myanmar and Chinese sides were really concerned about environmental issues and aimed at sustainable development of the country, there is no need for such a big dam to be constructed ... Instead two smaller dams could be built above Myitsone to produce nearly the same amount of electricity. BANCA (2009: 41-2; emphasis added)

At first glance BANCA (2009) appears to mediate between the arguments of the anti-dam and pro-dam coalitions. It rejects the Myitsone site as unacceptable and warns against the dam's negative ecological effects" However, it accepts the value of large hydropower, in the form of two unspecified smaller dams producing "nearly the same amount of electricity."

A Myanmar-based researcher told us that BANCA had identified several alternatives. We sighted an unpublished report with two alternative sites upstream of Myitsone, one on the N'Mai Kha, the other on the Mali Kha. Together, they would inundate a total of $118 \mathrm{~km}^{2}$, including 16 villages, compared to Myitsone's $405 \mathrm{~km}^{2}$ footprint and 32 villages to be inundated. Changjiang Survey Planning Design and Research Limited Corporation (2010) however rejected the proposal, and BANCA's final report BANCA (2009) did not identify the two alternatives (Interview Q).

Changjiang's EIA report (2010) did not include any argument that better alternatives to Myitsone might exist. Changjiang stated that its EIA was conducted in accordance with World Bank guidelines, including Bank policies around involuntary resettlement and indigenous peoples (2010: 3). A subsequent review of the EIA however found numerous shortcomings against best practices (International Rivers, 2013), including lack of authentic consultation with local communities (Kirchherr et al., 2016b). One expert described the BANCA (2009) report as "totally neglected" by Changjiang (International Rivers, 2013: 17). By September 2011, the EIA process under Changjiang's control drew repeated criticism inside Myanmar (Wai Moe, 2011; Zhu et al., 2016). In any case, the two smaller dams argument from Myanmar knowledge brokers appears to have influenced elite arguments over the case in 2010-11.

\subsubsection{Argumentative struggle and concession}

The period from mid-2011 to the President's concession in September is marked by an increase in argumentative struggle in the mass media, and notable elite divisions. As late as July 2011 (a month after the resumption of conflict disrupts access to the site), the President appears to consider the project viable (Su Mon Thazin Aung, 2011: 130). As noted in Section 6, the core executive appears to believe that concern over the impacts of Myitsone could be mitigated by social and environmental programs approved by the government.

Responding to the increased volume of anti-dam, pro-river coverage in private media outlets such as the Eleven Media Group, the stateowned New Light of Myanmar publishes in early August two more technical articles promoting the project's design, its ecological impacts, and its overall net benefits (Anonymous, 2011; Kyaw Min, 2011). The same week, citing the BANCA (2009) EIA report, Aung San Suu Kyi calls for a reassessment of the scheme, and endorses a campaign to save the Ayeyarwady (Aung San Suu Kyi, 2011). Pro-dam arguments harden. On 10 September, the Minister of Electric Power 1 Zaw Min gives a press conference, stating that:

some people are suffering from the currently popular 'Irrawaddy disease ... We will never backtrack from this project ... spoiling [Myitsone] in the pretext of environmental issues will undermine the interest of our country. We can achieve nothing from this. It's very simple. The country will get 10 per cent free power and 8 per cent commercial tax from this project ... (Mizzima, 2011; emphasis added)

The Minister discloses that he authored a recent anonymously- written article defending Myitsone's merits (i.e. Anonymous, 2011). Defending technocracy, he states no one in the country is "smarter than him in hydropower generation" (Mizzima, 2011). Similar claims about technical expertise and the public's inability to understand relevant issues are made by a senior member of the electric power ministry (Ko Pauk, 2011). Critics rebut Zaw Min's claims, arguing that the national interest lies in the perpetual survival of the river. They predict street demonstrations will follow (Mizzima, 2011). Six days later, U Myint, a well-known economist recruited to a senior advisory post, issues an open letter calling for a credible analysis of the project. He invokes the two smaller dams argument previously voiced by BANCA (2009).

[W]e should conduct an objective and independent economic and social impact analysis of the Myitsone dam project ... The possibility of a suitable alternative, such as building two small dams upstream that will yield the same amount of electricity could also be considered. Such an alternative, while bringing the same economic benefits, will have much less adverse economic, social, political and emotional impacts on the people of Myanmar ... (Anonymous, 2012a:148, emphasis added)

Within days of the above argumentative struggles, the government holds a workshop in Naypyidaw, which brings together high-level government officials, CPI, some civil society organisations, and journalists to discuss and debate the project (Wai Moe, 2011). If Save the Ayeyarwady launches the first "real national debate" in Myanmar in decades (International Crisis Group, 2011: 9), the 17 September workshop is possibly the first real attempt at public deliberation on hydropower. The arguments made there (Zhu et al., 2016; Chan, 2017; Su Mon Thazin Aung, 2017) reveal some senior government officials echoing opponents' arguments, representing Myitsone as a threat to Myanmar's ecology and society, and notably invoking the opponents' argument that alternative sites superior to Myitsone existed.

After the workshop, with ministerial divisions now evident, Minister Zaw Min is asked to devise a process, whereby parliament will decide on the project after two levels of specialists offer submissions (Su Mon Thazin Aung, 2017: 137). However, on 29 September 2011 (two days after Zaw Min's proposal) the President reportedly has a meeting with senior advisors from academia and think tanks who warn him of various "irreparable impacts" (Yeophantong, 2016b). He is described as being under "great pressure" during this time because of anti-Dam opposition (Chan, 2017), and increasingly receptive to arguments made by Soe Thein, Minister of Industry, to cancel or suspend the project (Su Mon Thazin Aung, 2017). Subsequently on 29 September, the President announces a decision to suspend Myitsone Dam at a ministerial meeting (Su Mon Thazin Aung, 2017). The President's subsequent announcement to parliament is not communicated in advance to CPI or Beijing (Chan, 2017).

\subsection{Presidential speech analysis}

We interpret the policy argument in the President' announcement of 30 September 2011 (New Light of Myanmar, 2011) as follows. The speech's underlying values are "democratic practices", "good governance", and "environmental conservation." Myanmar's goals are "peace and stability of the State" and national modernization. Issue representations include active peace-making efforts; electricity as essential for industrialization; the inadequacy of nuclear and coal-fired technologies; the inadequacy of natural gas under current arrangements (which privilege foreign investors); the availability of renewable hydropower energy; and a 30-year strategic plan for electricity with 64 planned hydropower projects, including eight upper Ayeyarwady projects (Fig. 3). In the speech, this brief reference to upper Ayeyarwady hydropower has the rhetorical effect of valuing the cascade scheme. However, Chinese implementation of the Myitsone project is then described as causing a wide array of "public concerns" (New Light of Myanmar, 2011). The "people's will" is that the cons of the project 
outweigh the pros. The conclusion is a claim for action to suspend the project:

As our government is elected by the people, it is to respect the people's will. We have the responsibility to address public concerns in all seriousness. So construction of Myitsone Dam will be suspended in the time of our government [i.e. to the end of 2015]. Other hydropower projects that pose no threat will be implemented through thorough survey for availability of electricity needed for the nation... (New Light of Myanmar, 2011; emphasis added)

The President's argument builds on common values of electrification and modernity. However, the proponents' value of depoliticized political order (Fig. 1) is notably re-cast as order based on democratic legitimacy. Issue representations include first pros of upper Ayeyarwady development, then cons consisting of opponents' concerns. By explicitly acknowledging proponents' pros and opponents' cons, the issue representation is more balanced than either the proponents' or opponents' arguments we reconstructed (Figs. 1 and 2). The means-goal argument is to implement other hydropower projects to meet Myanmar's electricity needs (as opposed to predominately for export) thus delivering on the combined goals of modernization, with peace and stability.

After this landmark decision, CPI and the Chinese government engage in various strands of advocacy and diplomacy aimed at persuading Myanmar civil society and government actors to re-consider their positions against the project (Chan, 2017; Kiik, 2016b; Zhu et al., 2016). Civil society representatives express frustration at the proponents' continued interest in Myitsone, without heeding the voices of local people, at a time of intensified suffering in Kachin (Interviews A, D, E).

\section{Discussion}

Although vitally relevant, the World Commission on Dams (2000) and other normative governance approaches were not designed to explore the actual dynamics which de-legitimate or legitimate energy development. What insights, then, does Myanmar provide? Some readers may regard Myitsone in Myanmar as too exceptional a case and context from which to glean general insights. We nonetheless offer three initial propositions:

(P1) Three processes - heightened public contention, elite intervention, and persuasive argument - are necessary to disrupt a cycle of declining policy legitimacy;

(P2) A weakened or disrupted policy regime expands opportunity to critique its dynamics;

(P3) The reform of a hydropower policy regime requires a multidisciplinary set of capabilities, and supportive institutional arrangements.

\subsection{Disrupting a failing policy regime}

Our analysis of Myanmar's Myitsone project to 2011 reveals a spiral of declining legitimacy of large hydropower - or to put it starkly, a failing policy regime (Sections 5-7). To recap: proponents' failure to defend Myitsone's superiority over other hydropower sites and other energy service options weakened their policy argument (Section 5). Their failure to discuss a range of alternatives resulted in an asymmetrical contest between a means - a hydropower dam - vs. a persuasive argument about ends, namely that the confluence site and the Ayeyarwady, as emblems of ethnic and national identity, and icons of heritage, should be preserved. Myitsone's institutional arrangements were inadequate (Section 6). Arrangements between proponents and the central government did not properly recognize Kachin State's dominant political actor (the KIO), civil society groups, or the broader population. Control over EIA findings by Changjiang, a party with conflicted interests, resulted in a lack of rigorous environmental and social assessment (Section 7.2.1).

Regarding the dynamics of support and opposition: the proponents' unpersuasive policy argument (Fig. 1), combined with remarkably inadequate institutional and implementing arrangements, caused grievances to accumulate among Kachin and later wider Burmese civil society. By 2011, the project coincided with Myanmar's emerging political transformation. As restrictions on freedom of expression began to ease, "saving the Ayeyarwady" became a cause unifying nationalist publics and a civil society seeking peace and socially inclusive development, against foreign commercial interests in a mega-project. The emergence of multi-level mobilization was not pre-destined. Instead it hinged on the critical arguments of Kachin villagers and leaders, amplified and reframed by lowland Myanmar advocates (Section 7). To dissipate political impacts that had already emerged, and foreseeable domestic social and political damage, a newly elected, nominally-civilian government withdrew its support. In so doing, it disrupted Myanmar's large hydropower policy regime. The case leads directly to the proposition that heightened public contention, elite intervention, and persuasive argument are necessary to disrupt a cycle of declining policy legitimacy.

\subsection{Critiquing a policy regime}

Our second proposition is that a weakened or disrupted policy regime offers enhanced opportunity to critique its performance. Section 7.2 showed the emergence of more elaborate as well as passionate antiand pro-dam arguments during 2009-2011. Some arguments heightened perceptions of policy illegitimacy. For example, a minister's charged statements during the second week of September 2011 (Section 7.2.2) triggered categorical rebuttals by anti-dam spokespeople (Mizzima, 2011) a week before the "climax" of the Save the Ayeywarwady campaign (Anonymous, 2012b; Chan, 2017: 9).

Elite actors also contributed to regime critique. After the 2011 decision, the Thein Sein government invited CPI to develop the six other upper Ayeyarwady sites (Fig. 3). CPI declined. We interpret its position - that no guarantee existed an alternative dam could avoid conflict and move to completion (Zhu et al., 2016) - not only as an acknowledgement of ongoing hostilities, but indirectly, as a rebuke of the policy regime's institutional arrangements (Section 6).

Likewise, following a series of Myistone-related meetings with Myanmar civil society and government in early 2012, a Chinese viceminister admitted the difficulty of monitoring and regulating stateowned enterprises such as CPI (Yeophantong, 2016a: 134). Another moment of policy regime critique occurs when the NLD's 2015 election manifesto endorses solar and wind energy technologies over large hydropower (National League for Democracy, 2015).

We interpret the 20-member "Myitsone Commission" established by the NLD government in August 2016, as a possible further instance of regime critique. Chaired by the Deputy Speaker of the Lower House, and comprised of officials and experts in a range of disciplines (Interview Q), the commission is tasked to assess hydropower proposals on the Ayeyarwady against international standards. Its terms of reference and methods have not been published. However, the commission's intention to incorporate the "voices and concerns" of local communities into its recommendations (Nyein Nyein, 2016) appears to repudiate the closed institutional arrangements of the Myitsone project.

\subsection{Capability and institutional requirements}

Our third proposition - that reform of a hydropower policy regime requires a multi-disciplinary set of capabilities, and supportive institutional arrangements - arises from the diversity of substantive issues raised by hydropower, the scope of analysis demanded by regime perspectives (Section 2), as well as the difficulty would-be reformers face to gain recognition.

Myanmar's capability for more holistic assessment of hydropower 
(e.g. BANCA, 2009, and the 17 September 2011 workshop) deserves to be augmented and supported with institutional arrangements. For example, a combination of institutional (Changjiang's control of the EIA process), and capacity-related challenges (the deaths during 2011 of two senior BANCA staff with specific knowledge) appears to have resulted in BANCA's version of the "two smaller dams argument" not being published. Deliberation around whether it is actually possible to generate "nearly the same amount" of electricity while avoiding the worst ecological and social impacts, remains to be pursued. Hydropower-related issues for actors to deliberate on include ecological connectivity for biodiversity and livelihood security (Ansar et al., 2014; ICEM, 2010; Ziv et al., 2012), and alternative energy development scenarios for Myanmar (e.g., Emmerton et al., 2015; Fullbrook, 2016; WWF et al., 2016), some of which have been offered by reformers. Deliberation may possibly be supported by multi-objective techniques (The Nature Conservancy et al., 2016). However, given technical complexity and risk of technocratic dominance, arrangements conducive to multi-stakeholder participation are required.

\subsection{Legitimizing energy policy regimes}

Despite largely sharing values around material modernity, Myitsone's proponents and opponents differ significantly on other values. The 2011 decision did not alter the positions of senior officials who support the project (Interviews F \& I), and the two sides talk and act past each other (Interviews A, D, E). A challenge for policy entrepreneurs is whether deliberative, multi-stakeholder processes (e.g. Kowalski et al., 2009) can bring citizens closer to a shared understanding of the "common good" around energy development in Myanmar (cf. Gilley, 2009a).

We propose that a shared understanding is advanced first by rationally persuasive hydropower-related argument. Second, it is advanced by effort to select projects based on transparent and multi-attribute comparison with hydropower alternatives (The Nature Conservancy et al., 2016) and with other means to deliver energy services (Fullbrook, 2016) and achieve inclusive development. Third, it is advanced by recognizing and incorporating peoples' preferences for social and ecological sustainability into project designs. Fourth, implementers will need to provide affected people with considerably greater benefits (Kirchherr et al., 2016a). Such a regime is unlikely to systematically favour large projects with inherently high demands on institutional capacity, and complex impacts and risks for communities, developers and societies.

\section{Conclusion}

We applied a policy regime perspective (specifically, a political economic regime of provisioning framework, PERP) to explore the dynamics of large hydropower legitimation in a developing and civil war-torn country context. We analyzed the persuasiveness of policy argument; the adequacy of key institutional arrangements; and the dynamics of actor support and opposition, which unfolded in a complex political economic context. In so doing, we demonstrated the importance and feasibility of seeking a holistic understanding of energy policy legitimation, and the utility of a PERP framework for such analysis.

Much remains to be understood about the Myitsone project, and its implications for energy policy legitimation in Myanmar. The 2011 suspension of Myitsone Dam disrupted the declining legitimacy of Myanmar's large hydropower policy regime. Despite the challenges of political economy and path dependency, the 2011 suspension may offer opportunities to work towards a more legitimate energy policy regime. Such opportunities include recognizing new actors and perspectives in Myanmar energy policy that have emerged since 2011; regarding social mobilization around Myitsone and other energy projects as feedback on policy legitimacy; and engaging citizens in the process of crafting more rationally persuasive arguments around energy options.

\section{Acknowledgements}

This paper is an output of the CSIRO Basin Management Outcomes Program, and the Mekong Program on Water, Environment and Resilience (M-POWER) Fellowship program. The authors thank Susan Cuddy, Nicholas Farrelly, Waleerat Foran, Tom Measham, Lorrae Van Kerkhoff, Kevin Woods, and multiple groups and individuals in Myanmar for their perspectives, insights, and assistance. We particularly acknowledge the contributions of three anonymous reviewers.

\section{Appendix A. Supplementary material}

Supplementary data associated with this article can be found in the online version at http://dx.doi.org/10.1016/j.enpol.2017.08.043.

\section{References}

Anonymous, 2008. Country report on progress of power development plans and transmission interconnection projects. Myanmar., Greater Mekong Sub-region. In: Proceedings of the Eighth Meeting of Regional Power Trade Coordination Committee (RPTCC-8)., Luang Prabang, Lao PDR, p. 34.

Anonymous, 2011. Perpetual natural heritage relayed with good volition. 9 August. New Light of Myanmar.

Anonymous, 2012a. Appendix (2012). Chronology of the Myitsone Dam at the confluence of rivers above Myitkyina. J. Curr. Southeast Asian Aff. 31, 141-152.

Anonymous, 2012b. We All Love the Ayeyarwady: Case Study on the Myitsone Dam Advocacy Campaign. Unpublished report.

Ansar, A., Flyvbjerg, B., Budzier, A., Lunn, D., 2014. Should we build more large dams? The actual costs of hydropower megaproject development. Energy Policy 69, 43-56.

Aung San Suu Kyi, 2011. Irrawady Appeal. 11 August 2011. 〈http://www. internationalrivers.org/files/attached-files/irrawaddy_appeal_by_dassk.pdf〉 (accessed 13 July 2015).

Ba Kaung, 2011. Burma's Vice-President Implicated in Kachin Massacres. 15 July. 〈http://www2.irrawaddy.com/article.php?Art_id = 21705\&page $=1\rangle$ (accessed 14 January 2017). The Irrawaddy.

BANCA [Biodiversity and Nature Conservation Association], 2009. Environmental Impact Assessment (Special Investigation) on Hydropower Development of Ayeyawady River Basin Above Myitkyina, Kachin State, Myanmar. Biodiversity and Nature Conservation Association, Yangon.

Callahan, M.P., 2007. Political Authority in Burma's Ethnic Minority States: Devolution, Occupation and Coexistence. Institute of Southeast Asian Studies, Singapore.

Chan, S.W.D., 2017. Asymmetric Bargaining between Myanmar and China in the Myitsone Dam Controversy: social opposition akin to David's Stone against Goliath. Pac. Rev.

Changjiang Survey Planning Design and Research Limited Corporation, 2010. Environmental Impact Report of Hydropower Development in Upper Reaches of Ayeyawady River. March 2010.

CSIRO, 2013. Change and Choice. The Future Grid Forum's Analysis of Australia's Potential Electricity Pathways to 2050. CSIRO Energy Transformed Flagship, Clayton, VIC.

Dean, K., 2005. Spaces and territorialities on the Sino-Burmese boundary: China, Burma1 and the Kachin. Political Geogr. 24, 808-830.

Dore, J., Lebel, L., 2010. Gaining public acceptance: a critical strategic priority of the World Commission on Dams. Water Altern. 3, 124-141.

Emmerton, M., Thorncraft, S., Oksanen, S., Soe, M., Hlaing, K.K., Thein, Y.Y., Khin, M., 2015. Final Report. Myanmar Energy Master Plan. Prepared for the Asian Development Bank and the Myanmar Ministry of Energy. December 2015. Project Number: TA No. 8356-MYA.

Flyvbjerg, B., 1998. Rationality and Power: Democracy in Practice. University of Chicago Press, Chicago.

Foran, T., 2006. Rivers of Contention: Pak Mun Dam, Electricity Planning, and State-Society Relations in Thailand. Division of Geography, Department of Geosciences, University of Sydney, Sydney, pp. 1932-2004. 〈http://hdl.handle.net/ 2123/1984>.

Foran, T., 2015. Node and regime: interdisciplinary analysis of water-energy-food nexus in the Mekong region. Water Altern. 8, 655-674.

Foran, T., Fleming, D., Spandonide, B., Williams, R., Race, D., 2016. Understanding energy-related regimes: a participatory approach from central Australia. Energy Policy 91, 315-324.

Foran, T., Wong, T., Kelley, S., 2010. Mekong Hydropower Development: A Review of Governance and Sustainability Challenges. Final Draft. Norwegian Water Resources and Energy Directorate, Oslo (accessed 21 May 2014). 〈http://splash-era.net/ downloads/mekong_report_part3.pdf $>$.

Fullbrook, D., 2016. Myanmar Electrification Assessment. Rethinking Electrification. Ministry of Agriculture, Livestock and Irrigation. DNV GL Energy, Singapore.

Gilley, B., 2009. The Right to Rule: How States Win and Lose Legitimacy. Columbia University Press, New York.

Greacen, C.E., Palettu, A., 2007. Electricity sector planning and hydropower. In: Lebel, L., 
Dore, J., Daniel, R., Koma, Y.S. (Eds.), Democratizing Water Governance in the Mekong Region. Mekong Press, Chiang Mai, pp. 93-126.

Hajer, M.A., 1995. The politics of environmental discourse: ecological modernization and the policy process. Clarendon Press, Oxford.

Hennig, T., 2016. Damming the transnational Ayeyarwady basin. Hydropower and the water-energy nexus. Renew. Sustain. Energy Rev. 65, 1232-1246.

Hla Hla Htay, 2007. Myanmar Cashes Up on Energy, But Locals in the Dark. 16 April. 〈http://www.burmanet.org/news/2007/04/16/agence-france-presse-myanmarcashes-up-on-energy-but-locals-in-the-dark-hla-hla-htay/ $\rangle$. (accessed 11 January 2017). Agence France Press.

ICEM, 2010. Strategic Environmental Assessment of Hydropower on the Mekong Mainstream. International Centre for Environmental Management, Hanoi Final Report. Prepared for the Mekong River Commission.

IEA, 2016. World Energy Outlook. International Energy Agency.

International Crisis Group, 2011. Myanmar: a New Peace Initiative. Asia Report No. 214. November 2011. 〈https://d2071 andvip0wj.cloudfront.net/214-myanmar-a-newpeace-initiative.pdf $\rangle$ (accessed 14 January 2017).

IRENA, 2016. The Power to Change: Solar and Wind Cost Reduction Potential to 2025. International Renewable Energy Agency.

John, P., 1998. Analysing Public Policy. Pinter, London.

Jones, L., 2013. The political economy of Myanmar's transition. J. Contemp. Asia 44, 144-170.

Jones, L., 2014. Explaining Myanmar's regime transition: the periphery is central. Democratization 21, 780-802

Kattelus, M., Rahaman, M.M., Varis, O., 2014. Myanmar under reform: emerging pressures on water, energy and food security. Nat. Resour. Forum 38, 85-98.

KDNG [Kachin Development Networking Group], 2007. Damming the Irrawaddy. 〈http://burmalibrary.org/docs4/Damming-the-Irrawaddy-eng.pdf〉 (Accessed 13 July 2015).

KDNG [Kachin Development Networking Group], 2009. Resisting the Flood. Communities taking a stand against the imminent construction of Irrawaddy dams. 〈http:// burmacampaign.org.uk/images/uploads/Resisting the Flood.pdf $\rangle$ (Accessed 1 September 2017)

Kiik, L., 2016a. Conspiracy, God's plan and national emergency: Kachin popular analyses of the ceasefire era and its resource grabs. In: Sadan, M. (Ed.), War and Peace in the Borderlands of Myanmar. The Kachin Ceasefire, 1994-2011. NIAS Press, Copenhagen, pp. 205-235.

Kiik, L., 2016b. Nationalism and anti-ethno-politics: why 'Chinese Development' failed at Myanmar's Myitsone Dam. Eurasia. Geogr. Econ. 1-29.

KIO [Kachin Independence Organization] Mali Nmai Confluence Dam Project. Letter from Lanyaw Zawng Hra to Chairman, Communist Party of China 2011.(accessed 14 July) 〈http://www.burmalibrary.org/docs11/KIO-Letter to China-red.pdf〉.

Kirchherr, J., Charles, K.J., Walton, M.J., 2016a. Multi-causal pathways of public opposition to dam projects in Asia: a fuzzy set qualitative comparative analysis (fsQCA) Glob. Environ. Change 41, 33-45.

Kirchherr, J., J. Charles, K., Walton, M.J., 2016b. The interplay of activists and dam developers: the case of Myanmar's mega-dams. Int. J. Water Resour. Dev. 1-21.

Kirchherr, J., Matthews, N., Charles, K.J., Walton, M.J., 2017. "Learning it the Hard Way": social safeguards norms in Chinese-led dam projects in Myanmar, Laos and Cambodia. Energy Policy 102, 529-539.

Pauk, Ko, 2011. Director of Hydro Power Implementation talks about Myitsone Dam. (accessed 22 May 2017). Mizzima. 16 September 2011.

Kowalski, K., Stagl, S., Madlener, R., Omann, I., 2009. Sustainable energy futures: methodological challenges in combining scenarios and participatory multi-criteria analysis. Eur. J. Oper. Res. 197, 1063-1074.

Kyaw Min, Lu, 2011. We Also Love River Ayeyawady. 10 August. New Light of Myanmar.

Lamb, V., Dao, N., 2017. Perceptions and practices of investment: China's hydropower investments in Vietnam and Myanmar. Can. J. Dev. Stud./Rev. Can. D.'études Dév. $1-19$.

Lichbach, M.I., Zuckerman, A.S. (Eds.), 1997. Comparative politics : rationality, culture, and structure. Cambridge University Press., Cambridge.

Limond, A., Aung, J., 2015. Dams, Drugs \& Democracy: The Struggle for Resources in Kachin State, Myanmar. Documentary. 60 min. 〈https://vimeo.com/145521800〉 (accessed 11 January 2017), p. $60 \mathrm{~min}$

Maung Aung, Myoe, 2013. The military and political liberalisation in Myanmar. In: Duell, K. (Ed.), Myanmar in Transition: Polity, People \& Processes. Konrad Adenauer Stiftung Ltd, pp. 57-64.

May, P.J., 2015. Implementation failures revisited: policy regime perspectives. Public Policy Adm. 30, 277-299.

May, P.J., Jochim, A.E., 2013. Policy regime perspectives: policies, politics, and governing. Policy Stud. J. 41, 426-452.

Mayntz, R., 2004. Mechanisms in the analysis of social macro-phenomena. Philos. Social. Sci. 34, 237-259.

McAdam, D., Tarrow, S., Tilly, C., 2001. Dynamics of Contention. Cambridge University Press, New York.

McCully, P., 1996. Silenced Rivers: The Ecology and Politics of Large Dams. Zed Books, London.

Mekong River Commission, Asian Development Bank, World Wildlife Fund, U.S. Agency for International Development, 2010. Rapid Basin-wide Hydropower Sustainability Assessment Tool (RSAT). September 2010.

Min, Zin, 2012. Burmese attitude toward Chinese: portrayal of the Chinese in contemporary cultural and media works. J. Curr. Southeast Asian Aff. 31, 115-131.

Missingham, B.D., 2003. The Assembly of the Poor in Thailand. From Local Sruggles to
National Social Movement. Silkworm Books, Chiang Mai.

Mizzima, 2011. Activists say they will step up work to protect the Irrawaddy River. 〈http://archive-1.mizzima.com/special-29517/myitsone-dam-controversy/5921 activists-say-they-will-step-up-work-to-protect-the-irrawaddy-river $\rangle$. (accessed 7 January 2017). 13 September 2011

Molle, F., Foran, T., Käkönen, M. (Eds.), 2009. Contested Waterscapes in the Mekong Region: Hydropower, Livelihoods, and Governance. Earthscan, London.

National League for Democracy, 2015. National League for Democracy 2015 Election Manifesto. Authorised Translation.

Natural Resources Governance Institute, 2014. Natural Resource Charter. Second Edition.

New Light of Myanmar, 2011. The Government i Elected by the People, and it has to Respect People's Will. Address by Thein Sein, President. Republic of the Union of Myanmar, Yangon (accessed 16 January 2017). 〈www.burmalibrary.org/docs12/ NLM2011-10-01.pdf.

Nyein, Nyein, 2016. New Commission to Decide Fate of Myitsone Dam in Kachin State. 12 August. 〈http://www.irrawaddy.com/news/burma/new-commission-to-decide-fateof-myitsone-dam-in-kachin-state.html > (accessed 13 January 2017). The Irrawady.

Perlez, J., 2006. Myanmar is Left in Dark, an Energy-Rich Orphan. 17 November. New York Times.

Ratner, B., Meinzen-Dick, R., May, C., Haglund, E., 2013. Resource conflict, collective action, and resilience: an analytical framework. Int. J. Commons 7.

Sadan, M. (Ed.), 2016. War and Peace in the Borderlands of Myanmar: The Kachin Ceasefire, 1994-2011. Nordic Institute of Asian Studies, Copenhagen.

Sayer, A., 1999. Realism and Social Science. SAGE Publications.

Simpson, A., 2013. Challenging hydropower development in Myanmar (Burma): crossborder activism under a regime in transition. Pac. Rev. 26, 129-152.

Simpson, A., 2014. Energy, Governance and Security in Thailand and Myanmar (Burma): A Critical Approach to Environmental Politics in the South. Ashgate.

Smits, M., 2016. Southeast Asian Energy Transitions: Between Modernity and Sustainability. Taylor \& Francis.

Snider, E., 2012. Electrical Industry of Burma/Myanmar. On-LineCompendium, Fourth ed. Burma Library Online.

Su Mon, Thazin Aung, 2017. Governing the Transition: Policy Coordination Mechanisms in the Myanmar Core Executive, 2011-2016. University of Hong Kong Ph.D. Thesis. $\langle$ http://hdl.handle.net/10722/240667〉.

Suhardiman, D., de Silva, S., Carew-Reid, J., 2011. Policy Review and Institutional Analysis of the Hydropower Sector in Lao PDR, Cambodia, and Vietnam. Final Report. International Water Management Institute, Vientiane.

Sun, Y., 2012. China's strategic misjudgement on Myanmar. J. Curr. Southeast Asian Aff. 31, 73-96.

The Nature Conservancy, WWF, University of Manchester, 2016. Improving Hydropower Outcomes Through System-Scale Planning: An Example from Myanmar. Arlington, VA.

Tilly, C., 1999. Conclusion: from interactions to outcomes in social movements. In: Giugni, M., McAdam, D., Tilly, C. (Eds.), How Social Movements Matter. University of Minnesota Press, Minneapolis, pp. 253-270.

Transnational Institute, 2011. Conflict of Peace? Ethnic Unrest Intensifies in Burma. Burma Policy Briefing Number 7. June 2011.〈https://www.tni.org/files/download/ bpb7.pdf> (accessed 9 July 2015). Transnational Institute and Burma Centrum Netherlands.

Wai Moe, 2011. Myitsone Controversy Sparks Discord in Naypyidaw. 19 September. 〈http://www2.irrawaddy.com/article.php?art id = 22103〉 (accessed 10 January 2017). The Irrawaddy. 19 September.

Watts, M., 2012. A tale of two Gulfs: life, death, and dispossession along two oil frontiers. Am. Q. 64, 437-467.

Webber, M., 2012. The political economy of the three gorges project. Geogr. Res. 50, 154-165.

Woods, K., 2011. Ceasefire capitalism: military-private partnerships, resource concessions and military-state building in the Burma-China borderlands. J. Peasant Stud. $38,747-770$.

World Bank, 2011. One Goal, Two Paths. Achieving Universal Access to Modern Energy in East Asia and the Pacific. The World Bank, Washington, D.C.

World Commission on Dams, 2000. Dams and Development: A New Framework for Decision-Making. Earthscan Publications Ltd., London.

WWF, IES [Intelligent Energy Systems], MKE [Mekong Economics Ltd.], 2016. Alternative Vision for Myanmar's Power sector. Towards Full Renewable Electricity by 2050. Draft. World Wildlife Fund.

Yeophantong, P., 2016a. China's Dam diplomacy in the Mekong Region: three game changers. In: Blake, D.J.H., Robins, L. (Eds.), Water Governance Dynamics in the Mekong Region. SIRD (Strategic Information and Research Development Centre), Kuala Lumpur, pp. 123-146.

Yeophantong, P., 2016b. China's hydropower expansion and influence over environmental governance in Mainland Southeast Asia. In: Goh, E. (Ed.), Rising China's Influence in Developing Asia. Oxford University Press, Oxford.

Yin, R.K., 2013. Case Study Research: Design and Methods. SAGE Publications, Thousand Oaks, CA.

Zhu, X., Foran, T., Fullbrook, D., 2016. Hydropower decision making in Myanmar: insights from Myitsone Dam. In: Blake, D.J.H., Robins, L. (Eds.), Water Governance Dynamics in the Mekong Region. SIRD (Strategic Information and Research Development Centre), Kuala Lumpur, pp. 149-177.

Ziv, G., Baran, E., Nam, S., Rodríguez-Iturbe, I., Levin, S.A., 2012. Trading-off fish biodiversity, food security, and hydropower in the Mekong River Basin. In: Proceedings of the National Academy of Sciences 109, 5609-5614. 